\title{
An input-output analysis of unit labour cost developments of the German manufacturing sector since the mid-1990s
}

\author{
Nora Albu ${ }^{1}$, Heike Joebges ${ }^{2^{*}}$ (D) and Rudolf Zwiener ${ }^{3}$
}

\begin{abstract}
According to empirical studies, a statistically significant factor for German exports success is high cost (or price) competitiveness. Studies by Deutsche Bundesbank recommend correcting the nominal effective exchange rate by broad cost (or price) indicators (Deutsche Bundesbank, 1998, 2016a). This would call for total economy unit labour costs. In contrast to these findings, Dustmann et al. (2014) suggest using refined unit labour costs for the exporting manufacturing sector only, corrected for inputs from other sectors and from abroad in an Input-Output $(\mathrm{IO})$ analysis framework. According to these authors' novel calculation, the export-oriented manufacturing sector of Germany experienced a decrease in unit labour costs by $25 \%$ between the mid-1990s and 2007 . We try to replicate their findings. Following standard approaches in calculating sectoral unit labours costs, correcting for inputs from other sectors and from abroad, and using consistent input-output data from the Federal Statistical Office and from the World Input-Output Database, nominal unit labour costs of the manufacturing sector did not decrease over the period of analysis, and developed similarly to total unit labour costs. The similarity to total economy costs is also confirmed for a more recent period. In contrast to these authors' claim, our findings are in line with recommendations of Deutsche Bundesbank for using total economy unit labour costs.
\end{abstract}

Keywords: Input-output analysis, German exports, Cost competitiveness, Unit labour costs, Real effective exchange rate, Manufacturing sector, Wage costs, Outsourcing

JEL Classification: C67, F16

\section{Introduction}

Export growth depends on several factors: price or cost competitiveness, non-price competitiveness, the structure of export products, growth in export destination countries, and, as a result, demand from these countries (see Altomonte et al., 2013; Karadeloglou \& Benkovskis, 2015 for overviews). Non-price competitiveness comprises the size of firms and technological capacities, taxation, access to finance, public support for research and development, and the location of the country that can

*Correspondence: heike.joebges@htw-berlin.de

${ }^{2}$ HTW Berlin, University of Applied Sciences, Berlin, Germany

Full list of author information is available at the end of the article explain geographical as well as product specialization (Altomonte et al., 2013).

Concentrating on cost (or price) competitiveness of a country's exports, the most prevalent indicator is the real effective exchange rate (REER), a weighted average of indexed nominal bilateral rates between countries, adjusted for relative movements of cost or price indicators of the respective countries. Even though manufactured goods dominate German exports, REER adjusted for unit labour costs of the manufacturing sector would yield a distorted picture of cost competitiveness of German exports, as they do not include the cost relieving effect of intermediate goods from other domestic sectors and imported intermediaries (Deutsche Bundesbank, 1998, pp. 41-45). Broad-based cost (or price) indicators 
perform better in explaining and forecasting German exports than narrowly defined ones (Deutsche Bundesbank, 1998, updated 2016a). Thus, total economy unit labour costs are seen as a better correction than sectoral unit labour costs.

Since the introduction of the euro, the focus for cost (or price) competitiveness has shifted from exchange rate movements, as they are no longer under national control, to national cost or price developments. For Germany, several authors see a pivotal role for export success in low unit labour cost developments (see Flassbeck \& Lapavitsas, 2012; Dustmann et al., 2014). Yet, in contrast to the Bundesbank's recommendation to concentrate on broad cost aggregates like total economy unit labour costs, Dustmann et al. (2014) stress that unit labour costs developments for the exporting manufacturing sector are the ones that should be scrutinized. Based on input-output (IO) coefficients for Germany, Dustmann et al. augment sectoral manufacturing unit labour costs for outsourcing of manufacturing production to the services sector. Additionally, they include imported inputs of the manufacturing industry. According to their novel method, unit labour costs of manufacturing exports decreased by a quarter during 1995 and 2007. Based on these findings, they claim that the real increase in German price competitiveness is higher than measured by OECD data for total economy unit labour costs. According to the authors, the enormous decrease in production cost "[...] has been the main reason for Germany's economic success over the last decade." (Dustmann et al., 2014, p.168).

Our paper replicates their calculations and discusses the novel approach in detail. We try to show that the approach is not fully convincing. Conducting a full input-output-analysis based on consistent IO data leads to estimates of unit labour costs in the manufacturing sector that do not differ in a relevant way from total economy unit labour costs. Given the delay in availability of IO data, we therefore recommend to stick to total economy unit labour costs for cost competitiveness considerations.

The next Sect. 2 will first summarize pros and cons of sectoral unit labour costs, before presenting the method for calculating these costs in Sect. 3, where we contrast our approach with the one used by Dustmann et al. (2014). Section 4 presents the findings, contrasting the authors' findings for the period 1995-2007 with our results. Section 5 discusses the underlying differences and implicit assumptions.. Section 6 replicates the calculation of manufacturing sector unit labour costs corrected for imported inputs and inputs from other sectors for the period 2000-2016. The findings are supposed to stress the result that total economy unit labour costs are an adequate indicator for unit labour costs of the exporting manufacturing sector. This period also allows for a refined correction of price developments. The last Sect. 7 concludes, pointing to the advantages of total economy unit labour costs.

\section{Background: total economy versus sectoral unit labour costs}

While relative unit labour costs can be shown to be relevant for cost competitiveness of exports, several authors discuss the appropriateness of sectoral over total economy unit labour costs: Total economy wages would include public sector as well as wages from private sectors like the services sector. Consequently, total economy unit labour costs are not always considered as adequate for determining the cost competitiveness of the export industry. The Bundesbank shows that for the peripheral euro area crisis countries the main driver of unit labour cost increases was mainly high public sector wages, not private sector ones (see Deutsche Bundesbank, 2016b). Similarly, Gaulier and Vicard (2012) stress that wage developments in non-tradable sectors (instead of exportoriented manufacturing sectors) triggered the overall increase in unit labour costs and prices in exports of peripheral euro area countries.

The "compendium on the diagnostic toolkit for competitiveness" argues that "measuring price competitiveness based solely on unit labour cost (ULC) developments risks conveying misleading signals" (Karadeloglou \& Benkovskis, 2015, p. 4). In times of increasing internationalization of trade, even wage and unit labour costs developments for individual sectors may be inappropriate as they hide inter-firm differences. Barba Navaretti et al. (2016) show that average productivity developments may mask very different distributions of company productivity, regarding the length of the tails and the skewed nature of the distribution. In addition, non-price competitiveness may be just as relevant (Karadeloglou \& Benkovskis, 2015).

Yet, recent studies find a statistically significant effect of REER based on total economy unit labour costs in estimations for export developments (see Leigh et al., 2017 for a sample of 60 advanced and emerging market countries; Deutsche Bundesbank, 2016a for a sample of 20 advanced countries with a focus on Germany). Dustmann et al. (2014) stress that total unit labour costs even overstate cost developments of the exporting manufacturing sector in Germany. The authors try explicitly to calculate adjusted unit labour costs for German exporting industries, only including those manufacturing segments where export shares are above $25 \%$.

Their approach is partly motivated by wage cost differences between the manufacturing and the services sector: Labour costs for the manufacturing sector in 


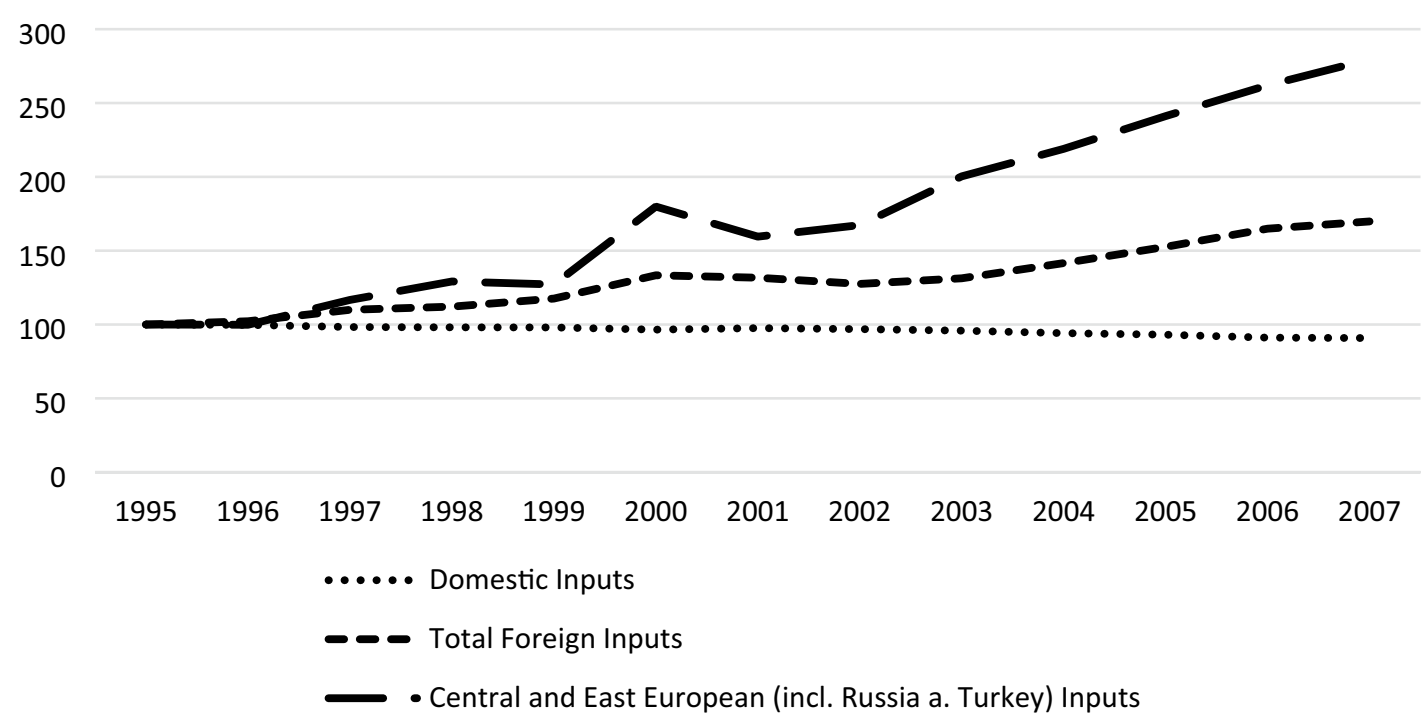

Fig. 1 Development of inputs relative to output (production value) for the German Manufacturing sector since 1995, 1995=100. Inputs relative to production value ("end product"); imports from Central and East European countries include those from Turkey and Russia; for further details see Appendix 1, 3, and Albu (2018). Source: Intercountry Input-Output Tables from World Input-Output Database, Release 2013 for the years 1995 to 2007; own calculations; $1995=100$

Germany have been much higher than for the services sector, in contrast to most other euro area countries (see Logeay et al., 2011; Hartwig \& Krämer 2017). The cost difference between the two sectors is highest in Germany and amounted to about 20\% during the 2000s (HerzogStein et al., 2015, p.7). Consequently, any outsourcing of activities to the services sector should lower wage costs of production in the manufacturing sector.

Yet, as we will show below, the correct procedure by which interlinkages between manufacturing and service sectors are included is quite complicated. Yet, in the following, we stick to the overall manufacturing sector instead of the exporting manufacturing sector, as the difference in unit labour costs is negligible (see Appendix 3, Fig. 6).

In order to exactly determine the wage-cost-relief effect for the German manufacturing sector through the use of domestic inputs from the services sector, Albu (2017) uses an input-output analysis. By taking the interdependence between the manufacturing sectors into account, the approach allows to measure and compare the overall labour costs of each final product, directly accounting for compensation of employees in production according to the different sectors. As the data provides information on wage costs per person in different production stages, a hypothetical value for macroeconomic labour costs can be calculated by statistically aligning the distribution of working hours of all production areas and their hourly wages with the distribution of working hours and hourly wages in manufacturing. Ludwig (2013) and Albu (2017) correct for the differences in full-time and part-time shares between the manufacturing and the services sector. Albu (2017) finds a wage-cost relief effect for the German manufacturing industry through the procurement of domestic services of between 8 and 10\%. Albu (2017) and Ludwig (2013) concentrate on direct and indirect labour costs effects, not unit labour costs.

Next to inputs from the services sector, imported inputs are another factor to correct for. The global trend towards greater world trade integration via global value chains, export processing, and other forms of trade integration also affects production in Germany, and as a result, exports. The contribution of imported inputs to value added of exports and imports for re-exports increased from 30\% in 1995 to about 44\% in 2006 (Loschky \& Ritter, 2007, p.485).

Imported intermediate products in manufacturing output increased from 1995 to 2007 by 70\%, as Fig. 1 shows. Imports increased especially from Central and East European countries (including Turkey and Russia). Consequently, total German domestic inputs have decreased during the same time, but still amount to about 66\% of overall total inputs in 2007 (Albu 2018). ${ }^{1}$ Ignoring inputs from other sectors and from overseas would indeed distort true unit labour costs in manufacturing, as Dustmann et al. (2014, p.173f) rightly state. We

\footnotetext{
${ }^{1}$ Similarly, Dustmann et al. (2014, p.174) calculate 70\%.
} 
therefore correct for it when calculating unit labour costs in manufacturing.

\section{Method: Measuring unit labour costs of the export industry}

Our paper replicates the approach by Dustmann et al. (2014): We calculate unit labour costs of the manufacturing sector based on a full input-output analysis, taking into account inputs from other domestic sectors and imported inputs. The standard calculation for sectoral unit labour costs (i.e., manufacturing labour costs) is gross wages and salaries plus social security contributions from employers in the (manufacturing) sector divided by persons employed (or hours of employment), in relation to productivity per person (or per hour) in that sector. Productivity per person (or per hour) is measured by real manufacturing gross value added divided by employment in persons (or hours) or labour force in that sector.

We try to stay as close as possible to the method used in Dustmann et al. (2014), yet, we stick to conventions: We calculate nominal unit labour costs for the manufacturing sector. We fully correct for interlinkages with other domestic sectors and for imported inputs by an inputoutput analysis, thereby focusing on value added of this sector. Calculations for unit labour costs in the German manufacturing sector that account for inter-sectoral linkages and imported inputs are based on national accounts data from the German statistical office (Destatis) and Intercountry Input-Output tables (WIOD), Release 2013 for the years 1995 to 2007, complemented by own calculations (see below). If necessary, we provide additional information on the data used in figures (see sources) and in appendices.

The authors use a simplified calculation for the tradable manufacturing sector (see additional materials for Dustmann et al. 2014 in the Online-Appendix, Figure 4 and Table A2). For the means of comparison between the Dustmann et al. (2014)-version of unit labour costs and our calculations, we mirror the authors' approach, but in contrast to Dustmann et al. (2014) we are using the methodologically consistent data provided by an input-output analysis (Albu 2018). Details will be explained below.

Dustmann et al. use a novel approach of calculating sectoral unit labour costs. We will try to explain the relevance of each particular assumption. While each particular step may have limited effects on calculated cost developments, the combination strongly affects the final result. As already explained, Dustmann et al. (2014) concentrate on the export-orientated manufacturing sector (those segments of the manufacturing sector with an export share above $25 \%$ ), but any difference with the total manufacturing sector regarding unit labour costs is negligible (see Appendix 3, Fig. 6). Consequently, we will concentrate on showing the effects for the whole manufacturing sector.

Particularities involve the following:

- The calculation for the "end product" instead of for the "value added",

- The calculation of "real" instead of "nominal" unit labour costs

- An inadequate correction for imported inputs by relying on coefficients for imported inputs instead of using global interlinkages

- An incomplete correction for inputs from other domestic sectors

- Usage of different data for numerator and denominator

Mostly, the effect of each of the particularities on the final cost-relief estimates is comparatively small. However, the use of real unit labour costs instead of nominal ones has an important effect on final cost-relief calculations. Furthermore, the largest effects arise from the usage of "end product" instead of "value added" and from the adjustment for inputs from other domestic sectors.

The authors motivate the concentration on unit labour costs for the "end product", instead of "value added", by arguing that this is important for correcting for inputs from other sectors as well as including imported inputs (Dustmann et al., 2014, pp.173-4). Yet, the corrections seems to be incomplete and inconsistent, as we will show below.

\section{Results for the period 1995-2007}

Figure 2 shows the effect of three differences to their approach: (1) We calculate unit labour costs for the value added instead of for the "end product", as this is the common indicator. (2) We use a full input-output-analysis based on the corresponding global IO-data in order to fully correct for interlinkages with other sectors. ${ }^{2}$ (3) We include all relevant wage costs. In order to be able to compare only these effects with their approach, we show the outcome for real unit labour costs (even though nominal costs are the relevant factor for cost competitiveness). The development we calculate is depicted by the interrupted line "Real Unit Labour Costs Total Manufacturing Global Interlinkages". As one can see in Fig. 2, real unit labour costs for this sector decrease in our approach by only $12 \%$, not by a quarter as in their publication. In

${ }^{2}$ Based on this approach, we do not only correct for the cost-relieving effect of imported inputs and inputs from other sector. This approach also takes into account that intermediate goods from the service sector may contain imported inputs. 

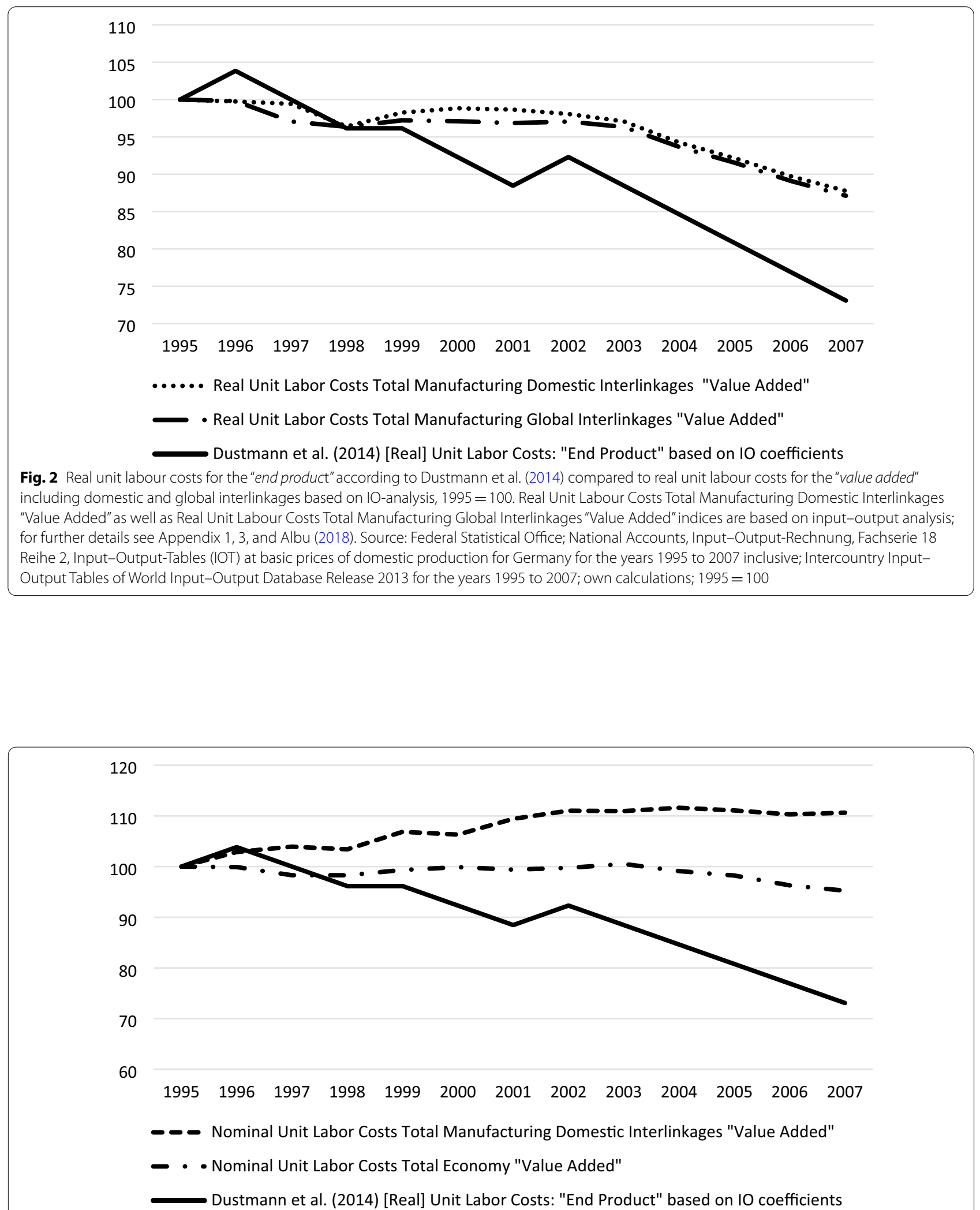

Fig. 3 Different measures and concepts of unit labour costs. For further details see Appendix 1, 3, and Albu (2018). Source: Dustmann et al,. (2014); Federal Statistical Office; National Accounts, Input-Output-Rechnung, Fachserie 18 Reihe 2, Input-Output-Tables (IOT) at basic prices of domestic production for Germany for the years 1995 to 2013 inclusive; own calculations; $1995=100$ 
Figs. 2 and 3, the bold line "Dustmann et al. (2014) [Real] Unit Labour Costs: 'End product' based on IO coefficients" always represents unit labour costs of the exporting manufacturing sector as calculated by Dustmann et al. (2014): in real terms, for the "end product", and based on IO coefficients in order to account for inputs from other sectors.

\section{Discussion of results for the period 1995-2007}

We judge the usage of IO coefficients for imported intermediate products instead of fully accounting for global interlinkages based on an IO-analysis and data sources as suboptimal due to the following reasons:

i. Usage of inconsistent data: While the authors use output variables from the Federal Statistical Office, they do not complement it with the consistent sectoral labour cost data available for this purpose for their IO calculations, but use instead data from the Sample of Integrated Labour Market Biographies (SIAB), coupled with IO coefficients (see Dustmann et al., 2014, Appendix B, Table 2a). The $\mathrm{SIAB}$ is a 2 percent random sample drawn from the Integrated Employment Biographies (IEB) of the Institute for Employment Research (IAB). By using this data set, several distortions occur: The specific development in East Germany is ignored and the changes in employers' social security contributions are not taken into account. Contrary to the authors' statement (Dustmann et al., 2014, p.171), the increasing wage spread in individual sectors cannot have any influence on the calculation of unit labour costs, as only average labour costs per capita are used for this purpose. In order to avoid these problems, we use instead national accounts data for Germany (including East Germany and employers' social security contributions).

ii. The authors calculate unit labour costs for the "end product" but only include domestic cumulative inputs (based on domestic IO coefficients), losing intercountry interlinkages. This methodological shift accounts for about 15 percentage-points difference of the final decrease in costs (see the dotted line "global Interlinkages" for the corrected value added approach that at the same time corrects for global interlinkages with other countries/sectors versus the bold line for Dustmann et al. (2014) "end product" in Fig. 2). This approach implies ignoring the wage costs incorporated in the imported inputs but using overall output at the same time. Given that imported inputs increased over the period studied by the authors, this approach generates a negative trend in the calculated indicator by con- struction. As a result, it is not surprizing that the unit labour costs for the end product calculated by Dustmann et al. decrease.

iii. The authors try to account for inputs from other sectors. Yet, instead of conducting a full IO analysis for the unit labour cost index, required from a methodological point of view, they use the coefficients of the inverted IO-matrix for including wage costs from other sectors. This approach does not correctly account for all interlinkages and economies of scope and, in particular, does not correct for differences in the share of part-time workers between sectors. The latter has a significant influence on the calculation of the cost advantages of the German industry relative to the industries of other countries in the use of cost-effective inputs from the services sector, as Ludwig (2013) and Albu (2017) show.

iv. The authors miss this redistribution in the denominator because no IO coefficients were used. The assumption that the end product contains the value added shares of the purchased intermediate consumption is only partially correct, since the deductions of value added for use of other intermediate consumption were not taken into account. This is particularly the case for the export-strong industries, since finished parts are exported in order to be reused.

v. Furthermore, Dustmann et al. justify the decision to measure unit labour costs on the basis of the industrial end product by the fact that not only upstream inputs from Germany but also those from abroad are to be included, since the production value includes all imports (Dustmann et al., 2014, p.176). In principle, nothing would stand in the way of the inclusion of imported intermediate inputs, especially as these have increased sharply over the period under study, especially imports of German manufacturing from Eastern Europe (Albu, 2018). However, the linkages with other countries are absent in the indicator Unit Labour Costs: "End Product", since the IO coefficients of Destatis used by Dustmann et al. in connection with the production value (Dustmann et al., 2014, Appendix B, Table A2) refer only to domestic production, excluding imports, and therefore do not offer weights for foreign inputs to production. In order to correctly account for imported inputs, the authors should have used global intercountry IOtables, provided e.g., by WIOD. ${ }^{3}$ Figure 2 shows

${ }^{3}$ WIOD provides an intercountry-Input-Output Table for the years 1995 to 2011 and 2000 to 2014. 
that the use of input coefficients stemming from global IO-tables for interlinkages and economies of scope would have led to a different development of unit labour costs including domestic interlinkages: lower in the second half of the 1990s and almost identical in the 2000s.

In contrast to the authors, we stick to calculating nominal unit labour costs that we deem more appropriate for measuring cost competitiveness. That the authors calculate real unit labour costs is a consequence of having nominal values for wages and salaries in the numerator and nominal values for output in the denominator, by using the nominal "end product" instead of real value added and IO coefficients of Destatis based on inputoutput tables with nominal values. If the indicator reflected total economy unit labour costs, it would serve as an indicator for income distribution (measuring the wage share of GDP in real terms), instead of an indicator for nominal costs per unit of output. ${ }^{4}$ While they argue that the difference between real and nominal unit labour costs is negligible, we show below that this difference amounts to about 10 percentage-points for the manufacturing sector and cannot be ignored (see Appendix 3, Fig. 9).

Correctly accounting for interlinkages stemming from intermediate inputs from other sectors, nominal unit labour costs even increase in the period from 1995 to 2007, since productivity in the services sectors is lower than industry's (Fig. 3). The overall lower productivity development resulting from the interlinkages with the services sector increases both real and nominal unit labour costs, i.e. irrespective of whether the production value or gross value added is used as the denominator in the calculation of productivity. This explains the surprising result that the inclusion of services sector inputs increases unit labour costs, due to the lower productivity in this sector. Yet, this effect might be overrated because the higher share of part-time workers in the service sector in fact lowers the measured productivity increase in this sector (Albu, 2017).

Ultimately, the authors' idea of including the interlinkages between the different sectors leads to a result in which the unit labour costs of industry, including the interlinking effects using the IO-methodology, show no decline at all in the period under consideration (line "Nominal Unit Labour Costs Total Manufacturing

\footnotetext{
${ }^{4}$ As the indicator only refers to the manufacturing sector, it cannot be considered as an indicator for income distribution.
}

Domestic Interlinkages 'Value Added" in Fig. 3) and are thus closer to unit labour costs of the total economy (line "Nominal Unit Labour Costs Total Economy 'Value Added" in Fig. 3). ${ }^{5}$

Based on this criticism, we think that the approach used by Dustmann et al. (2014) is not convincing and heavily understates true cost developments in the (tradable) manufacturing sector. Figure 2 demonstrates the effects of particularities in the approach by Dustmann et al. (2014): The use of "end product" instead of "value added" decreases unit labour costs by more than 10 percentage-points. Concentrating on real unit labour costs instead of nominal unit labour costs, adds another 10 percentage-points (see Fig. 9 in Appendix 3).

We agree with Dustmann et al. (2014) and Deutsche Bundesbank (1998, 2016a) that unit labour costs for the manufacturing sector are not a good indicator for the competitiveness of the German manufacturing export sector, as this indicator would ignore lower cost inputs from the service sector and from abroad. Yet, the replication of Dustmann et al. (2014) and the necessary corrections show that their particular approach is not convincing and overstates the decline. An indicator for nominal unit labour costs in manufacturing based on consistent IO coefficients and consistent data sources would even indicate increasing costs (see Fig. 4).

\section{Robustness check for the period 2000-2016}

In addition to the computation of nominal labour costs in manufacturing including domestic interlinkages based on a price index deflation (Albu 2018), we replicate the indicator using a refined measure (Albu, 2020) including two methodological differences with regards to the computation in Fig. 3: firstly, the price deflation used is based on a chain index deflation of the value added (denominator); secondly, the interlinkages computed are based on supply-use tables for industry classification (see Fig. 10 in Appendix 3).

\footnotetext{
${ }^{5}$ The increase of nominal unit labour costs for the total manufacturing industry including domestic interlinkages compared to the base year seems to be overestimated by about 10 percentage points in 2007 (as the gap between the development of real and nominal unit labour costs without interlinkages only makes up for about $10 \%$. This can be seen in figure A4 in appendix III). The calculated increase is mainly due to the partial unavailability of price indices for the respective period, especially for the service sectors (see Albu, 2018). Discounting the 10 percentage points difference from the nominal unit labour costs including interlinkages would a) decrease the gap in figure A6 (appendix III) to still about 25 percentage points between the nominal unit labour costs with interlinkages and Dustmann et al. (2014) adjusted version of the former and b) change the line "Nominal Unit Labour Costs Total Manufacturing Domestic Interlinkages 'Value Added" to be closer to unit labour costs of total economy (line "Nominal Unit Labour Costs Total Economy 'Value Added") in Fig. 3.
} 


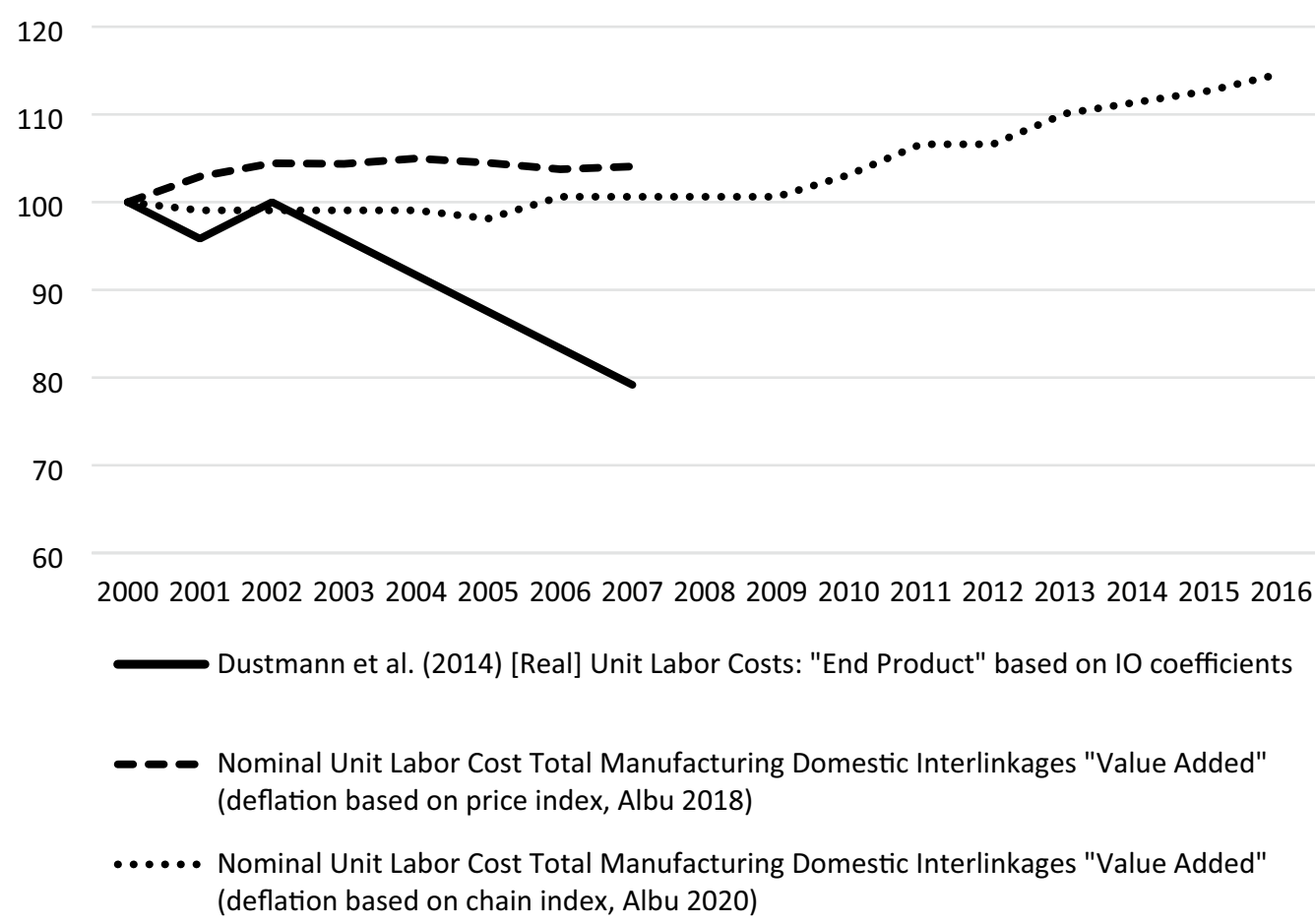

Fig. 4 Different Measures, Concepts and Deflation Methods of ULC. For further details see Appendix 1, 2, 3 and Albu (2018, 2020). The nominal unit labor cost total manufacturing domestic interlinkages "Value Added" (deflation based on chain index, Albu 2020) has been computed via IO-modelling in Albu (2020) for the years 2000, 2005, 2010, 2013, 2015 and 2016. All points in between are estimates based on averages for graphical purposes. Source: For both series ending in 2007, see source Fig. 3. For the series running up to 2016: Federal Statistical Office, National Accounts, Input-Output Accounts, Fachserie 18 Reihe 2, Input-Output-Tables (IOT) at basic prices of domestic production. Federal Statistical Office, National Accounts, Detailed Annual Results, Domestic Product Calculation, Fachserie 18 Reihe 1.4, 2018 edition

Figure 4 shows a level difference between the trend of the computation based on the price index deflation (Albu, 2018) and the computation based on the chain index deflation (Albu, 2020). Despite the level difference, which is mainly due to the deflation methods, neither of the two above-described computations of the indicator decreases within the period between 2000 and 2007 as does the indicator computed by Dustmann et al. (2014). We strongly believe that the methodological differences in the computation of the IO coefficients are the main source for the discrepancy.

As we replicate our calculation for the period 20002016 using a chain index deflation for industry classification, we are able to increase the data quality of the productivity of outsourced inputs to the services sector. For this period, the German Federal Statistical Office offers better price deflators for the services sector. Figure 5 shows that correctly and consistently calculated unit labour costs for the manufacturing sector develop closely to total economy unit labour costs.

Competitiveness is a relative concept. The calculated indicator is only informative if it is available for more countries than only Germany. As the share of manufacturing exports differs between countries, sectoral unit labour costs would have to be calculated matching the respective export composition. It would be required to include the cost effect resulting from the interdependence of inputs with other domestic sectors.

According to Deutsche Bundesbank, an ideal indicator "should draw on internationally comparable statistical data, be calculated for all countries using the same method, capture all internationally tradable goods as well as the factors required for their production, comprehensively represent the price and cost situation and be available in near time." (Deutsche Bundesbank 2016a, pp. 14-15). As one can see from the replication, correctly calculating the cost of manufacturing exports is time consuming, and subject to difficulties in measuring productivity and price indices in the service sector. In addition, it would imply long time lags because of the delay in data provision, which is violating the requirement of availability in near time.

We therefore suggest relying on total economy unit labour costs as an indicator for national cost competitiveness because of fast availability; this indicator would then have to be corrected by exchange rate changes and can 


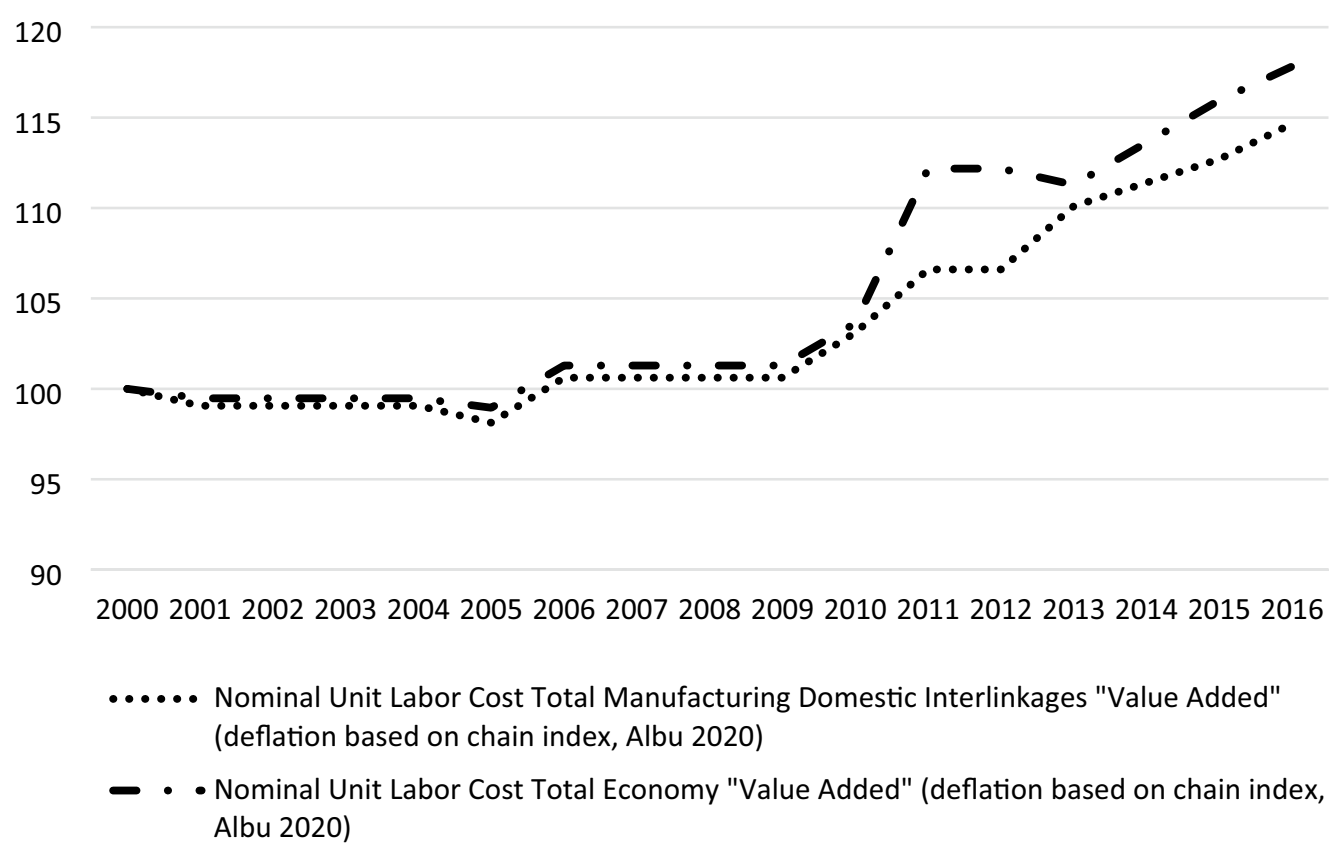

Fig. 5 Total economy unit labour costs vs. manufacturing unit labour costs including domestic interlinkages and imported inputs for the period 2000-2016. For further details see Appendix 2 and Albu (2020). The datasets for the nominal unit labour cost total manufacturing domestic interlinkages "Value Added" (deflation based on chain index, Albu 2020) as well as the nominal unit labour cost total economy "Value Added" (deflation based on chain index, Albu 2020) have been computed via IO-modelling in Albu (2020) for the years 2000, 2005, 2010, 2013, 2015 and 2016. All points in between are estimates based on averages for graphical purposes. Federal Statistical Office, National Accounts, Input-Output Accounts, Fachserie 18 Reihe 2, Input-Output-Tables (IOT) at basic prices of domestic production. Federal Statistical Office, National Accounts, Detailed Annual Results, Domestic Product Calculation, Fachserie 18 Reihe 1.4, 2018 edition. See sources for price deflation for the series $2000-2016$ in Fig. 4

more easily be compared to unit labour costs developments of trading competitors. Yet, we only concentrate on Germany. Showing the adequacy of total economy unit labour costs for other countries' exports has to be left for future research.

Our finding for Germany is in line with the findings of Deutsche Bundesbank:

"... there is some evidence to suggest that indicators based on broadly defined price and cost indices may be capable of modelling price competitiveness more appropriately than more narrowly defined indices, since the latter capture price and cost developments only in some subsectors of the domestic economy. For example, indicators based on unit labour costs in manufacturing, which were once in widespread use, cover only one part of relative cost developments. This is not necessarily representative of overall cost developments in the German economy and can therefore easily lead to distortions and misinterpretations. Price and cost indices that focus on macroeconomic variables avoid this disadvantage." (Deutsche Bundesbank, 2016a, p. 13).
Given these arguments, we recommend the use of total economy unit labour costs developments.

\section{Conclusions}

Cost competitiveness of exports is often measured by NEER developments corrected by unit labour cost developments of relevant trade partners. Since the introduction of the euro, the focus lies more on relative unit labour cost developments than on exchange rate developments. Some authors consider the relatively low-cost developments in Germany as the key element behind German export success. Dustmann et al. (2014) go even further by claiming that total unit labour costs would even hide the relative cost advantage. They claim that unit labour costs for manufacturing exports are relevant, taking into account low costs inputs from the services sector and from abroad. In order to measure the costs, they develop a new approach, according to which "true" unit labour costs decreased by $25 \%$ between 1995 and 2007. 
Yet, the new approach for sectoral unit labour costs from Dustmann et al. (2014) does not stand up to closer scrutiny. Replicating their results with the help of IO analysis and discussing the implicit assumptions, we show that this indicator is methodologically extremely problematic and clearly exaggerates Germany's competitive strength. Using consistent data and consistent IO coefficients, and sticking to standards, we show that nominal unit labour costs of the manufacturing sector, corrected for inputs from services sector and from abroad, even increased slightly during the period under study, 1995 to 2007.

We additionally calculate unit labour costs in manufacturing for the period 2000 to 2016, and again correct for imported intermediate products as well as for inputs from other domestic sectors. For this period, available data allows for a better correction of price developments. As we show, corrected sectoral unit labour costs closely match the ones for total economy.

Yet, this approach is highly time consuming and would have to be conducted for all trade partners. As IO data is only published with delay, we recommend instead using total economy unit labour costs as a competitive indicator, as this takes the effects of low wages and productivity in the German service sector into account in a methodologically sound way and is available on a timely basis. This finding is in line with recommendations from Deutsche Bundesbank (1998, 2016a). Replications for other countries require further research.

\section{Appendix 1}

Sources for price-adjustment for the period 1995-2007

Figures 2 and 3 show the change in nominal unit labour costs of the German manufacturing sector with domestic interlinkages based on price index deflation. The following statistics used for the price index deflation are provided by the German Federal Statistical Office:

- Producer price indices of agricultural products: Germany, years, Fachserie 17 Reihe 1, Price indices for agriculture and forestry;

- Producer price indices of products of logging from state forests: Germany, years, Fachserie 17 Reihe 1, Price indices for agriculture and forestry;

- Index of producer prices of industrial products: Germany, years, goods index (GP 2009), Fachserie 17 Reihe 2, Prices and price indices for industrial products (producer prices);

- Consumer Price Index: Germany, years, Classification of Individual Consumption Purposes (COICOP), Fachserie 17 Reihe 7;
- Construction price indices: Germany, years, Fachserie 17 Reihe 4, Price indices for the construction industry;

- Wholesale price index: Germany, years, economic activities (WZ 2008), Fachserie 17 Reihe 6;

- Index of retail prices: Germany, years, economic activities (WZ 2008), Fachserie 17 Reihe 7;

- Producer price indices for transport and logistics services: Germany, years, economic activities (WZ 2008), Fachserie 17 Reihe 9.2;

- Producer price indices for business-related services: Germany, years, economic activities (WZ 2008);

For the price adjustment of gross value added, production values, as well as gross fixed capital formation, we used the price-adjusted chain indices from the Federal Statistical Office, National Accounts, Detailed Annual Results, Domestic Product Calculation, Fachserie 18 Reihe 1.4, 2016 edition.

\section{Appendix 2}

\section{Data and sources for price-adjustment for the period 2000-2016}

Figures 4 and 5 show the change in nominal unit labour costs of the German manufacturing sector with domestic interlinkages compared to those of the economy as a whole. The sources used for the computation of the indicator based on chain index deflation are provided by the German Federal Statistical Office:

- Federal Statistical Office, National Accounts, InputOutput Accounts, Fachserie 18 Reihe 2, Input-Output-Tables (IOT) at basic prices of domestic production.

- Federal Statistical Office, National Accounts, Detailed Annual Results, Domestic Product Calculation, Fachserie 18 Reihe 1.4, 2018 edition.

The different datasets described above capture the institutional delineation (industry classification with regards to product classification) of manufacturing for the indicator's nominator, i.e., nominal compensation of employees, and its denominator, i.e., real gross value added, by economic sector. This delineation is in line with the base tables, i.e., the supply and use tables, used to calculate domestic interlinkages as presented by Lenzen and Rueda-Cantuche (2012). The use and supply tables are not subject to price deflation within this computation. We deflated gross value added values by sectors using chain-linked indices from "Fachserie 18 Reihe 1.4". 


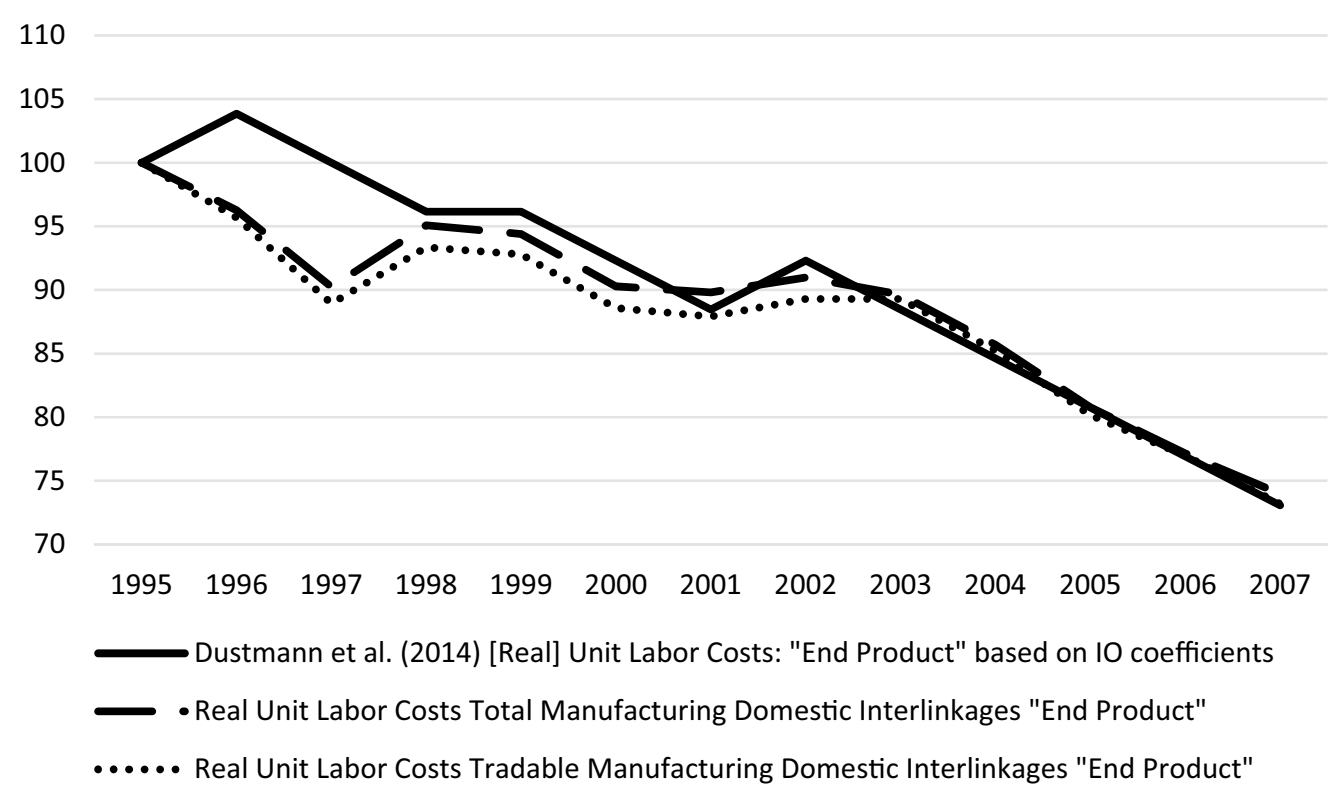

Fig. 6 Real manufacturing unit labour costs for the end product. For further details see Albu (2018). Source: Federal Statistical Office; National Accounts, Input-Output-Rechnung, Fachserie 18 Reihe 2, Input-Output-Tables (IOT) at basic prices of domestic production for Germany for the years 1995 to 2007 inclusive; own calculations; $1995=100$

\section{Appendix 3}

Detailed results for the period 1995-2007

Figure 6 shows the difference between a methodological inconsistent curve, i.e. Dustmann et al. (2014) [Real] Unit Labour Costs: "End Product" based on Input-Output coefficients and SIAB panel wage cost data, and a methodologically correct curve, i.e. Real Unit Labour Costs Tradable Manufacturing Domestic Interlinkages "End Product". The aim of this figure is first to show that a correct calculation of domestic inputs (leaving all other particularities aside) would change the development of unit labour costs mainly during the period of the second half of the 1990s. Second, as the dotted and dashed lines are quite similar, the figure also tries to exemplify that unit labour costs for the entire manufacturing industry do not differ in a relevant way from those of the exporting industry ("Tradable Manufacturing"), if measured by export shares above $25 \%$.

It is important to note that the correct incorporation of domestic interlinkages combined with the correction for the other peculiarities (real instead of nominal values, end product instead of value added) leads to rather important changes in developments of unit labour costs (see below, especially A6).
Calculating unit labour costs for the end product instead of for value added makes a huge difference (of about 20 percentage-points in 2007). This can be seen in Fig. 7.

Accounting for sectoral inputs by using the inverted IO-coefficients based on Destatis for domestic production (as in Dustmann et al., 2014), instead of IO-coefficients that account for imported inputs from global tables, changes the development of unit labour costs (see Fig. 8). In contrast to Figs. 6, 8 shows the changed development for domestic and foreign inputs ("Global interlinkages").

Calculating nominal instead of real unit labour costs makes a huge difference (of about 10 percentage-points in 2007). This can be seen in Fig. 9.

Calculating nominal instead of real unit labour costs for value added instead of for the end product PLUS correctly including domestic interlinkages (domestic inputs from other sectors) leads to even increasing unit labour costs for the manufacturing sector (see Fig. 9).

See Fig. 10 and Fig. 11. 


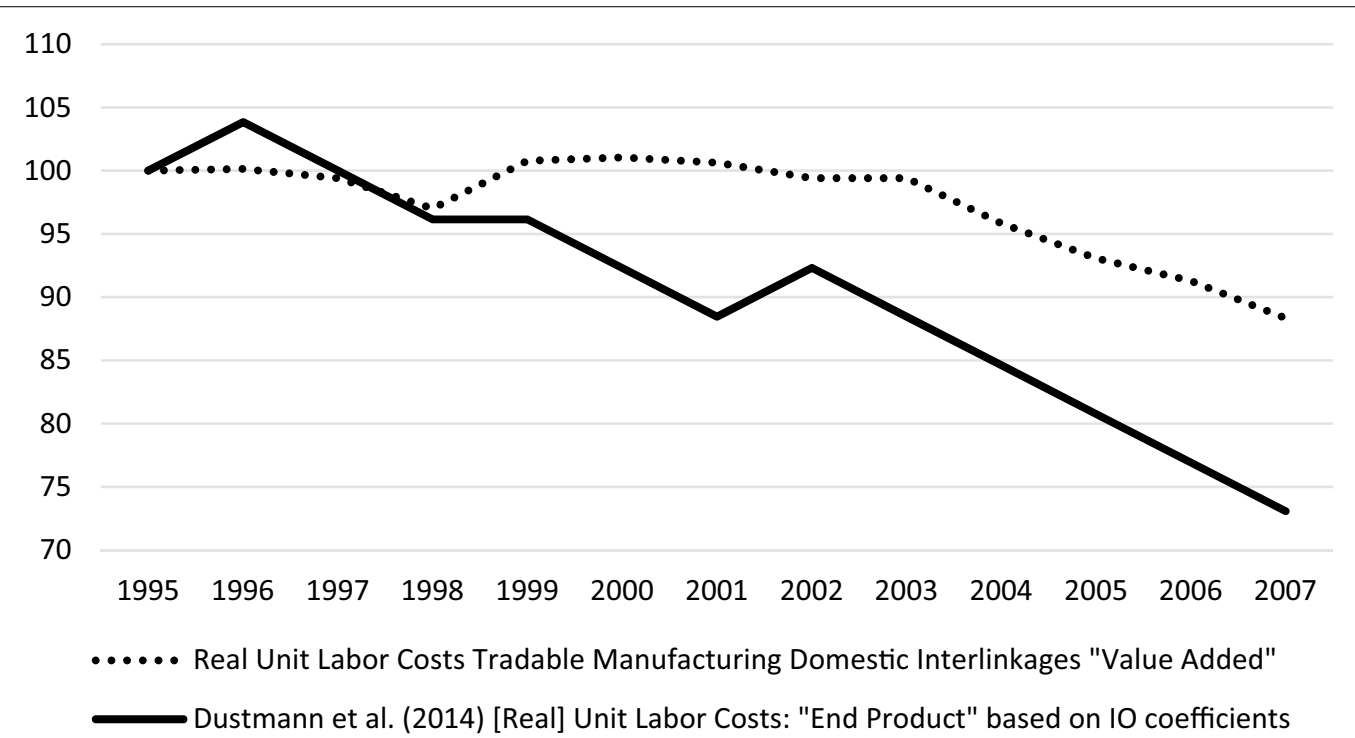

Fig. 7 Manufacturing unit labour costs for the end product vs. for value added. For further details see Dustmann et al. (2014). Dustmann et al., 2014, Appendix B Table A2; Federal Statistical Office; National Accounts, Input-Output-Rechnung, Fachserie 18 Reihe 2, Input-Output-Tables (IOT) at basic prices of domestic production for Germany for the years 1995 to 2007 inclusive; own calculations; 1995=100

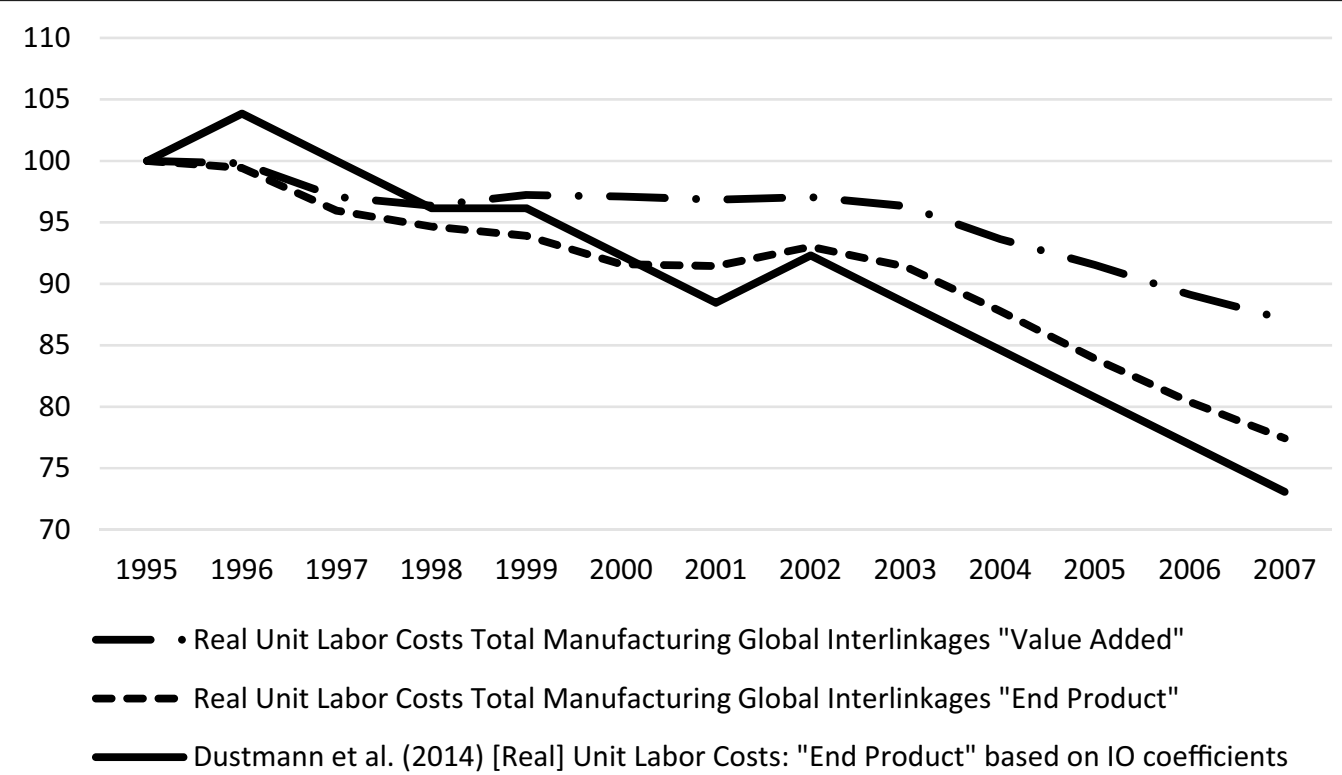

Fig. 8 Manufacturing unit labour costs based on correct IO-coefficients. For further details see Albu (2018). Dustmann et al., 2014, Appendix B Table A2; Intercountry Input-Output Tables of World Input-Output Database Release 2013 for the years 1995 to 2007; own calculations; $1995=100$ 


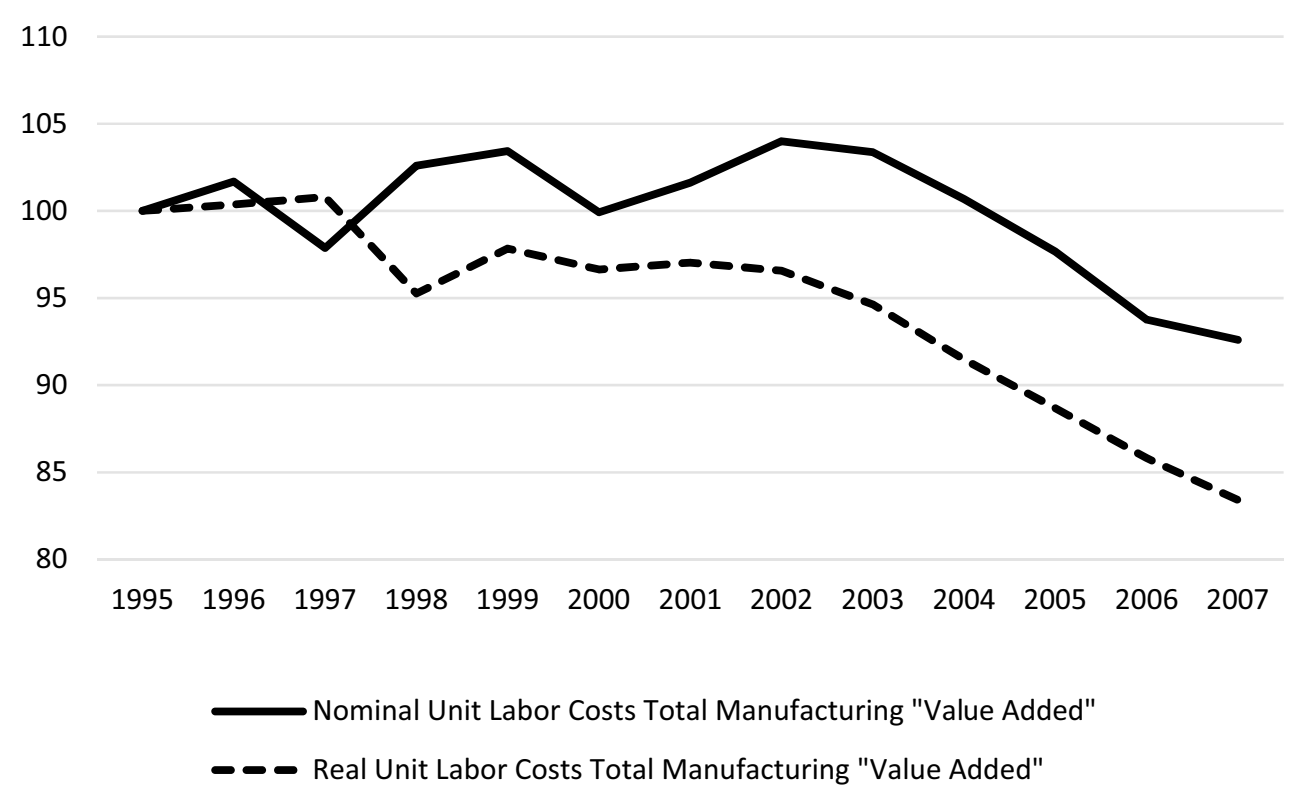

Fig. 9 Nominal versus real manufacturing unit labour costs for value added. For further details see Albu (2018). Federal Statistical Office; National Accounts, Input-Output-Rechnung, Fachserie 18 Reihe 2, Input-Output-Tables (IOT) at basic prices of domestic production for Germany for the years 1995 to 2007 inclusive; the price-adjusted chain indices from the Federal Statistical Office, National Accounts, Detailed Annual Results, Domestic Product Calculation, Fachserie 18 Reihe 1.4, 2016 edition; own calculations; 1995 = 100

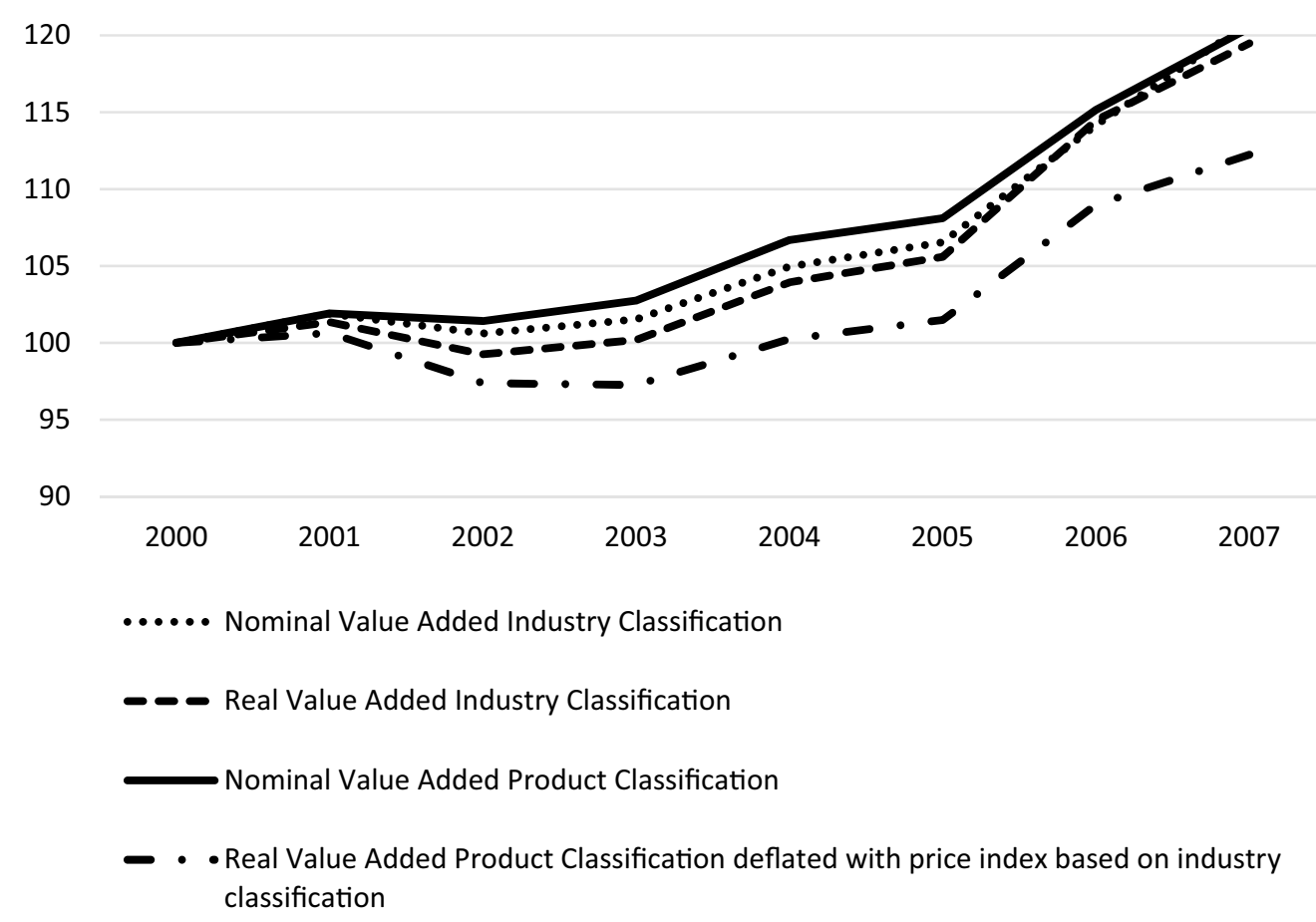

Fig. 10 Nominal versus real value added industry versus product classification. Federal Statistical Office; National Accounts, InputOutput-Rechnung, Fachserie 18 Reihe 2, Input-Output-Tables (IOT) at basic prices of domestic production for Germany for the years 2000 to 2007; Federal Statistical Office, National Accounts, Detailed Annual Results, Domestic Product Calculation, Fachserie 18 Reihe 1.4, 2018 edition.; own calculations; $2000=100$ 


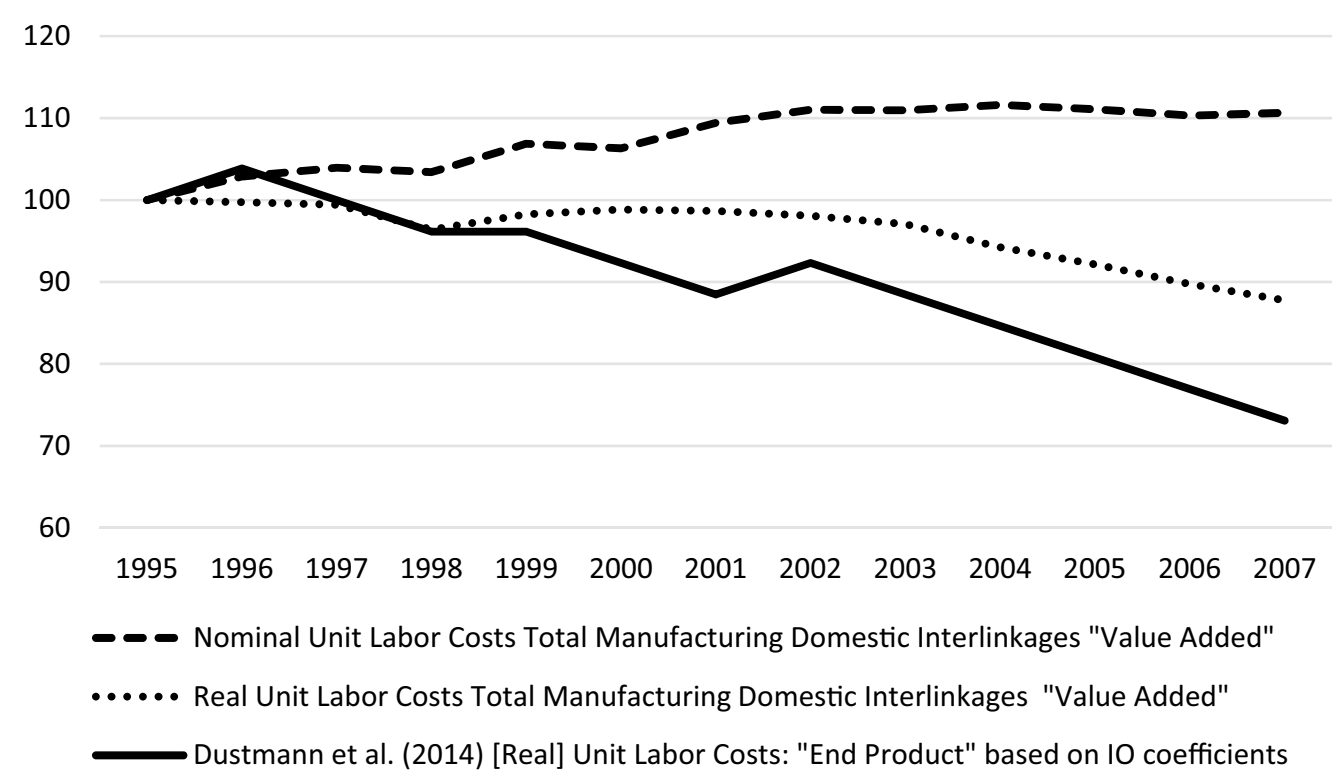

Fig. 11 Nominal versus real manufacturing unit labour costs for value added including domestic interlinkages. Notes: for further details see Albu (2018). Source: Dustmann et al., (2014); Federal Statistical Office; National Accounts, Input-Output-Rechnung, Fachserie 18 Reihe 2, InputOutput-Tables (IOT) at basic prices of domestic production for Germany for the years 1995 to 2007 inclusive; own calculations; $1995=100$

\section{Acknowledgements}

We are grateful for comments and suggestions received from Camille Logeay (labour market expert) and Udo Ludwig (IO expert) as well as from participants of an Economics Seminar at IMK. We especially thank Bernd Fitzenberger for clarifying comments, as well as anonymous referees from refereeing process of the Journal for Labour Market Research.

\section{Authors' contributions}

NA conducted the input-output analysis for the different measures of unit labour costs in the German manufacturing sector. $\mathrm{HJ}$ and RZ are responsible for discussing the findings and connecting it to total economy unit labour costs developments. Both the authors read and approved the final manuscript for submission.

\section{Funding}

NA received funding from the macroeconomic policy institute (IMK) at the Hans-Boeckler-foundation for conducting an in-depth input-output analysis of German unit labour costs developments in the manufacturing lecture. Her findings have been published as Albu (2018, see above). The publication served as a basis for the article we submit to the journal. For the other authors, funding issues are not applicable.

\section{Availability of data and materials}

We use freely available, official data: Calculations for unit labour costs in the German manufacturing sector that account for inter-sectoral linkages and imported inputs are based on national accounts data from the German statistical office (Destatis) and Intercountry Input-Output tables (WIOD). The text briefly explains the calculations. The following articles served as a basis for the IO-analysis and provide an in-depth explanation: Albu (2018) and Albu (2020). Both are freely available.

\section{Declarations}

Ethics approval and consent to participate Not applicable.

\section{Consent for publication}

All authors consent that the text and any pictures published in the article will be freely available on the internet and may be seen by the general public. The pictures and text may also appear on other websites or in print, may be translated into other languages or used for commercial purposes.

\section{Competing interests}

Not applicable.

\section{Author details}

${ }^{1}$ Institute for Economic Research (WifOR Institute), Berlin, Germany. ${ }^{2}$ HTW Berlin, University of Applied Sciences, Berlin, Germany. ${ }^{3}$ Formerly Macroeconomic Policy Institute (IMK), Düsseldorf, Germany.

Received: 8 February 2021 Accepted: 10 January 2022

Published online: 02 February 2022

\section{References}

Albu, N.: Arbeitskosteneffekte des Vorleistungsbezugs der deutschen Industrie unter Berücksichtigung der Arbeitszeiten. Eine Untersuchung mit der Input-Output-Methode. Gutachten des WiFOR Berlin im Auftrag des Instituts für Makroökonomie und Konjunkturforschung der Hans-BöcklerStiftung. IMK Study, No. 56. urn:nbn:de:101:1-201707123568 (2017)

Albu, N.: Lohnstückkosten des deutschen Verarbeitenden Gewerbes: inländische und globale Verflechtungen. Eine Untersuchung mit der InputOutput-Methode. Gutachten des WIFOR Berlin im Auftrag des Instituts für Makroökonomie und Konjunkturforschung der Hans-Böckler-Stiftung. IMK Study, No. 63. urn:nbn:de:101:1-2019022615104243706892 (2018)

Albu, N.: Nominale Lohnstückkosten des deutschen Verarbeitenden Gewerbes: Inländische Verflechtungen - Eine Untersuchung mit der InputOutput-Methode. Gutachten des WIFOR Berlin im Auftrag des Instituts für Makroökonomie und Konjunkturforschung der Hans-Böckler-Stiftung. IMK Study, No. 69. urn:nbn:de:101:1-2020071014395035820116 (2020)

Altomonte, C., di Mauro, F., Osbat, C.I.: Going beyond labour costs: how and why 'structural'and microbased factors can help explaining export 
performance? COMPNET Policy Brief, No. 01. https://doi.org/10.2866/ 32532 (2013)

Barba Navaretti, G., Bugamelli, M., Forlani, E., Ottaviano, G.: The importance of micro data in assessing aggregate outcomes. In: Altomonte, C.; Békes, G. (eds.): Measuring competitiveness in Europe: resource allocation, granularity and trade. BRUEGEL Blueprint Series, Vol. XVIV, pp. 14-25. https:// doi.org/10.1093/cesifo/ift002 (2016)

Deutsche Bundesbank: The indicator quality of different definitions of the real external value of the Deutsche Mark. Deutsche Bundesbank, Monthly Report No. 11, Frankfurt/Main, November, pp. 39-52 (1998)

Deutsche Bundesbank.: The impact of alternative indicators of price competitiveness on real exports of goods and services. Deutsche Bundesbank, Monthly Report No. 1, Frankfurt/Main, January, pp. 13-24. https://www. bundesbank.de/resource/blob/707538/850808bd2b6527bce2a51fe77 c6155fb/mL/2016-01-impact-data.pdf (2016a)

Deutsche Bundesbank.: Wage dynamics amid high euro-area unemployment. Deutsche Bundesbank, Monthly Report No. 12, Frankfurt/Main, December, pp. 33-54. https://www.bundesbank.de/resource/blob/ 707622/f75c2130dd74efc44b065a904fac882c/mL/2016-12-wage-data. $\operatorname{pdf}(2016 b)$

Dustmann, C., Fitzenberger, B., Schönberg, U., Spitz-Oener, A.: From sick man of Europe to economic superstar: Germany's Resurgent Economy. J Econ Perspect 28(1), 167-188 (2014). https://doi.org/10.1257/jep.28.1.167

Flassbeck, H., Lapavitsas, C.: The systemic crisis of the euro: true causes and effective therapies. Rosa Luxemburg Stiftung Studien. http://www.rosal ux.de/fileadmin/rls_uploads/pdfs/Studien/Studien_The_systemic_crisis_ web.pdf (2013)

Gaulier, G., Vicard, V.: Current account imbalances in the euro area: competitiveness or demand shock? Bulletin de la Banque de France: Quarterly selection of articles, Issue 27, pp. 5-26. https://publications.banquefrance.fr/sites/default/files/medias/documents/quarterly-selection-ofarticles_27_2012-autumn.pdf (2012)

Hartwig, J., Krämer, H.: 50 Jahre Baumol'sche Kostenkrankheit. Wirtschaftsdienst 97(11), 793-800 (2017). https://doi.org/10.1007/s10273-017-2216-0

Herzog-Stein, A., Joebges, H., Niechoj, T., Stein, U., Zwiener, R.: Nur moderater Anstieg der Arbeitskosten in Deutschland. Arbeits- und Lohnstückkostenentwicklung 2014 und 1. Halbjahr 2015 im europäischen Vergleich. IMK Report, No. 109. urn:nbn:de:101:1-201602178265 (2015)

Karadeloglou, P., Benkovskis, K. (eds.) and the CompNet Task Force.: Compendium on the diagnostic toolkit for competitiveness. ECB Occasional Paper Series, No. 163. http://hdl.handle.net/10419/154616 (2015)

Leigh, D., Lian, W., Poplawski-Ribeiro, M., Szymanski, R., Tsyrennikov, V., Yang, H.: Exchange rates and trade: a disconnect? IMF Working Paper, WP/17/58. https://www.imf.org/en/Publications/WP/Issues/2017/03/15/ExchangeRates-and-Trade-A-Disconnect-44746 (2017)

Lenzen, M., Rueda-Cantuche, J.M.: A note on the use of supply-use tables in impact analyses. SORT 36(2), 139-152 (2012)

Logeay, C., Stephan, S., Zwiener, R.: Driving forces behind the sectoral wage costs differentials in Europe. IMK Working Paper, Vol 10 urn:nbn:de:101:1-201202285249 (2011)

Loschky, A., Ritter, L.: Konjunkturmotor Export. Statistisches Bundesamt: Wirtschaft und Statistik, Issue 5, pp. 478-488. https://www.destatis.de/ DE/Methoden/WISTA-Wirtschaft-und-Statistik/2007/05/konjunkturmotorexport052007.pdf;jsessionid=4109C15B9D848A28FAF3F6818F6058FE. internet8722?__blob=publicationFile (2007)

Ludwig, U.: Arbeitskosteneffekte des Vorleistungsbezugs der deutschen Industrie unter Berücksichtigung der Arbeitszeiten. Eine Untersuchung mit der Input-Output-Methode. Gutachten im Auftrag des Instituts für Makroökonomie und Konjunkturforschung in der Hans-Böckler-Stiftung, IMK Study, No. 34. http://hdl.handle.net/10419/106249 (2013)

\section{Publisher's Note}

Springer Nature remains neutral with regard to jurisdictional claims in published maps and institutional affiliations.

\section{Submit your manuscript to a SpringerOpen ${ }^{\odot}$ journal and benefit from:}

- Convenient online submission

- Rigorous peer review

- Open access: articles freely available online

- High visibility within the field

- Retaining the copyright to your article

Submit your next manuscript at $\boldsymbol{\Delta}$ springeropen.com 